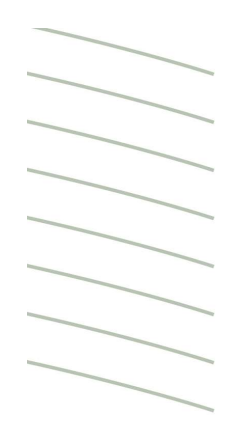

\title{
ANZTLA and the
}

\section{ALIA Professional}

Development Scheme:

\section{a survey}

by Kerrie Burn

Library Manager, Mannix Library, Catholic Theological College, University of Divinity

\section{Introduction}

At the 31st ANZTLA Conference in Canberra in 2016, several presentations were held at the National Library of Australia. In Judy Brooker's presentation, ALIA's Director of Learning highlighted the benefits of ALIA's Professional Development (PD) Scheme. ${ }^{1}$ This scheme is open to all Associate (Librarian) or Library Technician members of ALIA.

Subject specialisations were introduced by ALIA as an extension to its PD Scheme. Members can demonstrate their specialised knowledge by focusing their learning and PD activities on subject-related competencies. Each specialisation has a minimum of eight competencies. The subject specialisations that existed at the time of the Canberra conference included: Research/Academic, Health, Public Library, Schools, and Government. In 2017 two new specialisations were added: Data Specialisation, and the Vocational Education and Training (VET) Library Specialisation. Data had previously been a stream in the Research/Academic Specialisation. In 2018 another two new 
specialisations were announced: the LIS Practitioner Research Specialisation, and the Indigenous Engagement Specialisation, bringing the total number of specialisations to ten. Each of these has its own subject-specific competencies, although there are some areas of overlap. The Research/Academic Specialisation is based on competencies which address the unique opportunities and challenges within the research and tertiary education sectors. This is the specialisation that is currently of most relevance to theological librarians. There are three streams: general, research, and academic libraries (teaching and learning).

After Judy's presentation the question of whether a "Theology" Specialisation might be useful for ANZTLA members was discussed by several attendees. It may be that "theological librarianship" already aligns well with the Research/Academic specialisation. Alternatively, it may be that there are some unique competencies that are distinctive to theological librarianship. Before pursuing these questions any further we wanted to determine how many people within the ANZTLA community were also members of ALIA and/or ALIA's PD Scheme.

\section{The Survey}

A short, four-question survey was distributed via the ANZTLA-forum on 8 August 2016 in order to gather the required information. The survey questions were prepared using Survey Monkey. Participants were also invited to contribute additional comments related to professional development in the theological library environment. By 24 August 2016 there had been a total of 41 survey responses received. These are detailed below.

\section{Question 1 - Are you eligible for professional membership of the Australian Library and Information Association (ALIA)? If required see:}

https://membership.alia.org.au/membershipinformation/eligibility/eligibility

\begin{tabular}{|l|l|l|l|l|l|}
\hline & $\begin{array}{c}\text { Yes } \\
\text { (Associate/ } \\
\text { Librarian) }\end{array}$ & $\begin{array}{c}\text { Yes (Library } \\
\text { Technician) }\end{array}$ & No & Skipped & Total \\
\hline Responses & 35 & 3 & 2 & 1 & 41 \\
\hline Percentages & 87.50 & $7.50 \%$ & $5 \%$ & 0 & $100 \%$ \\
\hline
\end{tabular}




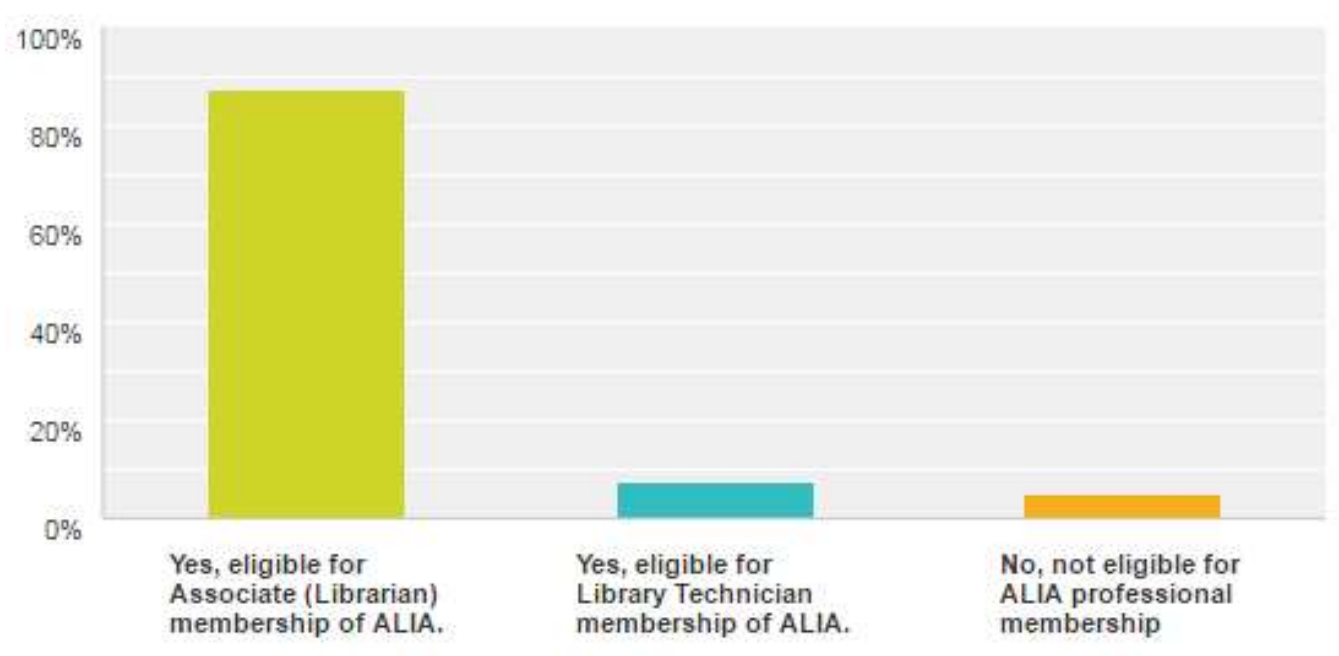

One respondent that was currently ineligible for professional membership of ALIA indicated that they were studying and would be eligible upon completion. They currently had student membership with ALIA.

\section{Question 2 - Are you a current member of ALIA?}

\begin{tabular}{|c|c|c|}
\hline Answer & Responses & Percentage \\
\hline Yes & 21 & $51.22 \%$ \\
\hline No & 20 & $48.78 \%$ \\
\hline Total & 41 & 100 \\
\hline
\end{tabular}

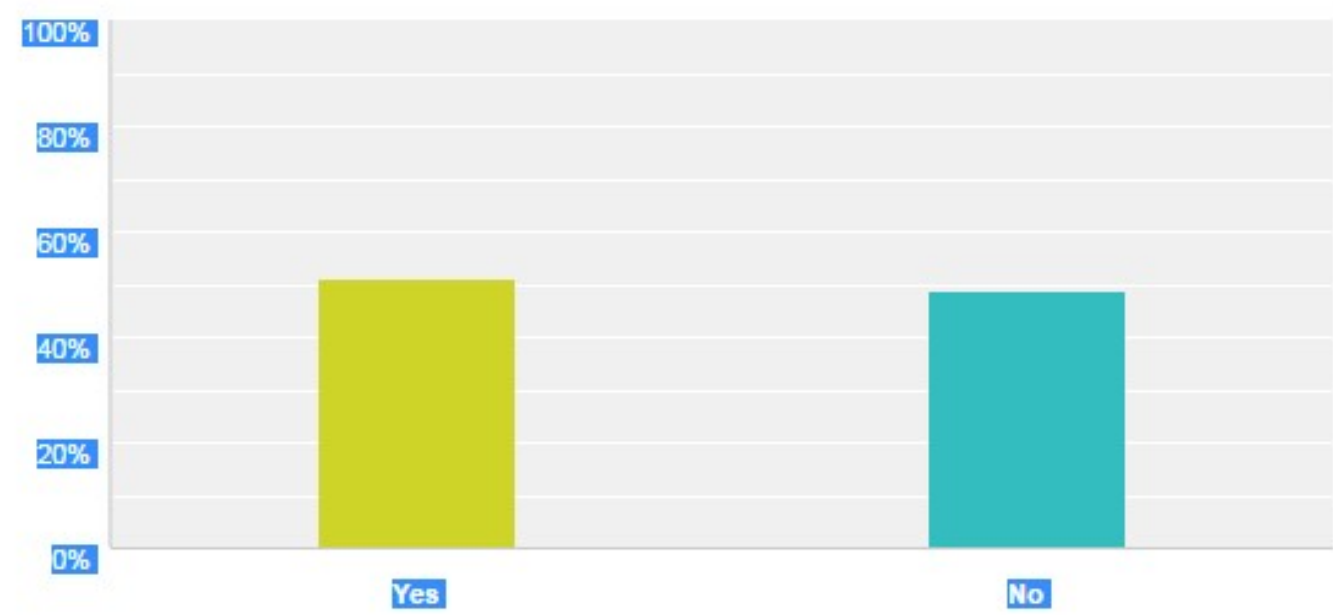




\section{Question 3 - Are you a current member of ALIA's Professional Development Scheme?}

\begin{tabular}{|c|c|c|}
\hline Answer & Responses & Percentage \\
\hline Yes & 12 & $29.27 \%$ \\
\hline No & 29 & $70.73 \%$ \\
\hline Total & 41 & 100 \\
\hline
\end{tabular}

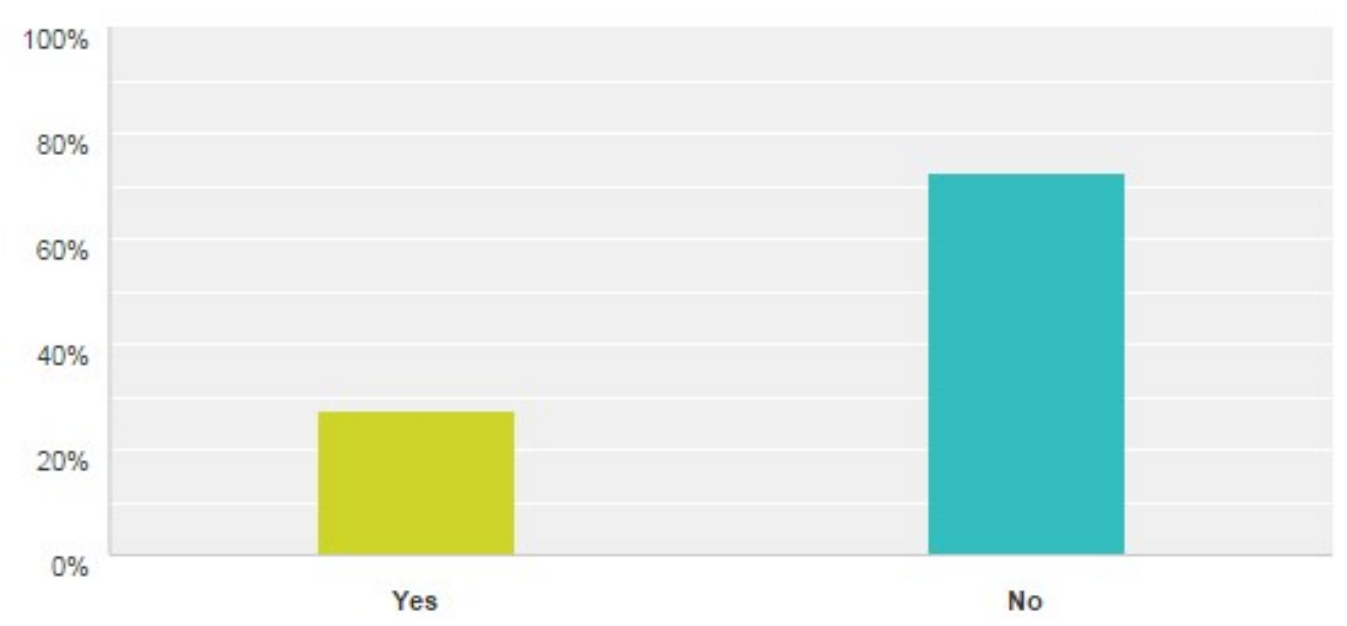

One respondent indicated that they were not a current member of ALIA's PD scheme but that they had registered with the PD tracking tool so that they could become a member when they completed their study.

Another respondent that was eligible for Library Technician membership of ALIA said that they had a Bachelor of Library Technology and were currently studying to upgrade to Librarian status. They noted, "Not that it will make a difference job wise, it just allows me to have the title I am operating at". They were a current member of ALIA and of ALIA's PD Scheme. Although already a member of the PD Scheme they commented that they need to activate this so the learning activities they engage in will be accredited towards certification.

Another respondent that was eligible for Associate (Librarian) membership of ALIA but not a current member of ALIA or ALIA's PD Scheme commented that "Like many librarians in Australia, the reason I am not a member of ALIA is the membership fee which neither I nor my Library can justify paying." The cost of membership was mentioned by several respondents. One noted that "Our College used to be an Institutional Member back when it was useful for getting ILL vouchers to pay 
for ILLs. The \$ cost of membership to the Individual Librarian seems quite high. I perceive that it is not particularly relevant to theological Libraries and Librarians, but maybe if there was a sub-group I would join and go to meetings." They were eligible for Associate (Librarian) membership of ALIA but were not a current member of ALIA or ALIA's PD Scheme.

One respondent indicated that they had been a member of the ALIA PD Scheme since 2003.

Others suggested that time management issues and needing to prioritise PD may be factors for those who had not yet joined ALIA or its PD scheme. Responses included comments such as, "I need to get around to joining." Another respondent that wasn't currently a member of the ALIA PD Scheme indicated that they planned to join since receiving information at the ANZTLA conference.

Question 4 - Do you have any particular comments that you would like to make about professional development in the theological library environment?

Nineteen responses were received to this question. All are detailed below, although some have been slightly edited to ensure anonymity.

1. I am working in an academic environment, so consider that the Research/Academic specialisation works well for me.

2. I'm not aware of any PD happening.

3. There may be some additional competencies that it would be good to identify that relate specifically to work in a theological library. The theological library world is generally a much smaller and less resourced environment compared to larger university libraries, and this requires some additional skills.

4. It definitely requires subject knowledge e.g. church denominations, figures in church history, theological terms etc.

5. More PD is needed in our sector. It is quite isolated, especially in one-person libraries so more opportunities tailored to our sector would be good. Probably a lot of University sector PD would be applicable but, then again, maybe not because University sector PD would assume a large University budget which Theological Colleges do not have. It would be a challenge to present things which were relevant to the sector but affordable.

6. I find the ANZTLA conferences to be most valuable for professional development, although I do attend local ALIA events where relevant, and also staff development sessions offered by local University (available to us as an affiliated body).

7. I've been in the general track for years (majoring on Academic activities), the cpd email suggestions are excellent, the scheme is definitely worthwhile but I think a Theology track may 
not be sufficiently distinctive and also may contribute to us being a bit 'inbred". Being forced to look at academic library developments in general is good discipline as it shows us "what is possible" not "what is available cheaply/ we can afford."

8. A theology specialisation is very useful for ANZTLA members resulting in dissemination of knowledge for those in the subject area. Research/Academic specialisation is a broad umbrella. Focus on theology specialisation is more helpful for the practitioners in this field and a more profitable use of time at conferences.

9. It should be made a priority. We need to develop transferable skills to enable us to work in other types of libraries, and not just theological ones. This will make us more employable.

10. It could be a useful tool to suggest commitment to our particular field. I don't know how much work would be involved for ANZTLA, though.

11. Many theological librarians work either alone or in libraries with few staff, so informal training from more experienced librarians, or librarians with a different experience, is often limited. There is often little or no technical support or training.

12. Attending ANZTLA annual conference is one huge professional development injection. I don't attend many ALIA PD seminars/workshops due to the cost factor and lack of time

13. Theological libraries are wide ranging - from large university to small. The 'in-between' space is difficult for the small \& medium to do what the large are able - staff, budget, expertise. This is why ANZTLA is such a valuable source of information sharing and support. To have even more support via ALIA would be very positive.

14. It would be useful to identify key components that are unique to theological libraries to assist professionals who are new to the environment, particularly those who work alone, to ensure they develop all necessary skills and knowledge.

15. I think PD in the theological area overlaps the academic area somewhat as most will operate in a tertiary environment, involves users and producing learning resources, cataloguing, digitising, information retrieval etc. The subject area is narrower than many tertiary institutions; I think that would be the main difference.

16. I was inspired by someone's talk years ago to keep a record of professional development but I just can't find the time these days.

17. Cost would play a big part in considering greater involvement.

18. I would be interested in seeing a 'theological specialization' in the PD scheme.

19. Could aim for $5-10$ standards that people in a theological library need to know to perform the job 


\section{Challenges, Questions and Conclusions}

This survey reveals that only about half of the ANZTLA members surveyed are also members of ALIA (51.22\%). Even less are members of the ALIA PD Scheme (29.27\%). Comments from respondents suggest that there are a number of factors that influence these membership decisions. These include the cost, perceived lack of time, and a view that the benefits of membership would not be as relevant to their own library environment.

The comments about professional development in the theological library environment were wide ranging. A number expressed an interest in having a theological specialisation in the ALIA PD Scheme but others felt that the broader Research/Academic library specialisation was very relevant and would assist librarians to develop transferable skills that would make theological librarians more employable in the wider sector and lead to them being less "inbred". While PD relevant to librarians working in the academic sector would generally be relevant to theological librarians, university libraries tend to have larger PD budgets, while smaller theological libraries may not have a PD budget at all. This makes some relevant PD activities inaccessible. Another area of concern was the isolation of some theological librarians who may work alone and therefore have little opportunity to learn on-the-job from a more experienced colleague. In a solo librarian environment, librarians may not be able to attend PD activities because it would leave their libraries unattended.

The role of professional development for theological librarians may be an issue that ANZTLA wishes to engage with more in the future. Opening up this conversation and undertaking further research in this area could lead to a range of possible outcomes. ANZTLA may like to consider reviewing the current list of competencies for the specialisations included in the current ALIA PD Scheme. This would help to determine whether they adequately address the requirements of those working in the theological library environment. However, even if a new "theological specialisation" and corresponding list of competencies was created within the ALIA PD Scheme, it would not be of benefit to a large number of theological librarians who are not currently members of the scheme. However, continuing professional development is vital if ANZTLA members are to maintain their skills and keep up-to-date with developments in the theological education, and broader higher education sectors. ANZTLA may wish to address some of the barriers or challenges that currently limit the ability of individual members to engage in PD activities.

Anecdotal evidence suggests that it is also becoming increasingly difficult to recruit good quality librarians who also have a theological background. While it is not necessary for a theological librarian 
to have a theological qualification to be employed, having such a qualification is certainly an advantage. This has led librarians at the University of Divinity to propose recently that newly appointed librarians with limited or no theological background be able to undertake theological studies as part of their employment contract. This proposal has yet to be approved but it does provide just one example of how a need for more theological knowledge on the part of new employees might be met.

Further research could also be undertaken to investigate the value that theological librarians place on their own professional development. This may be influenced by perceptions held more generally about the profession of librarians. Institutional support for professional development of library staff may also be determined by whether librarians are regarded as professionals in their own right, or merely as support workers within the broader academic environment. It is unfortunate that "librarians often seem to fall in the "blind spot" for academics and theological educators rather than being identified and valued for the significant role they play as part of the theological education team." ANZTLA may wish to take a more active role in advocating for the value of continuing professional development for members of its association. ALIA has also recently announced 2020 Pathways $^{3}$, a new means to gain formal recognition for commitment to ongoing professional development. This may assist members to be recognised as the professionals that they are. This, in turn, may facilitate theological librarians being allocated appropriate PD time and being adequately funded by their employers for PD activities.

If ANZTLA does take a more active role in supporting the ongoing learning of its members, it will need to determine the best way to do this. How it answers some of the following questions will help to decide the best path forward. Should support for professional development be done within the ALIA framework, a similar but separate scheme within ANZTLA, or some other alternative? Could ANZTLA take a more active role in promoting appropriate $\mathrm{PD}$ activities, and also provide a means for members to record and reflect on these activities? Would ANZTLA be interested in providing a way to recognise this commitment to ongoing professional development, and how would it do this? Historically, ANZTLA established its own organisation that was separate from the national library associations of Australia and New Zealand. Other specialist groups, such as health librarians, have remained under the umbrella of ALIA. Would the time ever come when ANZTLA would consider a similar arrangement, and work more closely with ALIA? Rather than ALIA, would ANZTLA be better off partnering with Atla, particularly with Atla's recent rebranding and its more international focus. At the 29 $9^{\text {th }}$ ANZTLA Conference held in Melbourne in 2014, the Executive Director of ATLA 
at the time, Brenda Bailey-Hainer spoke of opportunities for professional collaboration and development. She noted that as a professional membership organisation Atla "creates continuing education and PD opportunities for its members, including an annual conference, online webinars, and support for regional workshops". ${ }^{4}$ Whatever direction ANZTLA ultimately takes, the future of professional development for theological librarians in Australia and New Zealand will continue to involve ANZTLA members collaborating regionally, nationally, and internationally, with likeminded organisations that share a common purpose.

\section{References}

${ }^{1}$ Australian Library and Information Association. Professional Development Scheme. Accessed 23 May 2019. https://membership.alia.org.au/pdinfo/alia-pd-scheme

${ }^{2}$ Burn, Kerrie. "Theological Librarianship in Australia and New Zealand." In The Theological Librarians Handbook, Vol. 1, edited by Matina Ćurić. Publication of the Atla International Theologice Librarianship Education Task Force. Chicago: Atla Press, 2019 forthcoming.

${ }^{3}$ Australian Library and Information Association (ALIA). Professional Development. 2020 Pathways. Accessed 23 May 2019. https://membership.alia.org.au/documents/item/142

${ }^{4}$ Bailey-Hainer, Brenda. "Infinite Possibilities: The Future of Theological Librarianship." The ANZTLA EJournal, no. 13 (2014): 6-18. https://doi.org/10.31046/anztla.v0i13.511 